\title{
ANALYSIS SPEECH ACT OF BALI LANGUAGE TEACHERS IN BALI LANGUAGE LESSONS IN CLASS MANAGEMENT IN SMAN 2 KUTA
}

\author{
I Putu Ady Andyka Putra ${ }^{1}$, I Nyoman Sedeng ${ }^{2}$ \\ Universitas Udayana, Denpasar 80114, Indonesia
}

\begin{abstract}
This study aims to describe the Balinese language speech of Balinese language teachers in class management activities at SMAN 2 Kuta and describe the violations of the principle of Grice's cooperation. In addition, this study aims to determine the role of Balinese speech in supporting classroom management activities. The theories used in this study are speech act theories proposed by Yule regarding speech functions. This research is a qualitative research. This research uses descriptive analysis method that describes the string of words or sentences. The technique used in this research is note taking and recording techniques. The data in this study in the form of teacher's speech in classroom management activities at SMAN 2 Kuta. The results of this study can be described as follows. First, in class management activities, the declarative speech function spoken by the teacher is as much as $12.20 \%$, namely speech classifying, prohibiting, and forgiving. Representative utterances spoken by the teacher as much as $53.65 \%$ include speech shows, speculation, states, and acknowledge. Expressive speech spoken by the teacher as much as $7.32 \%$ includes speech praising and insinuating. Speech directive spoken by the teacher as much as $17.07 \%$ includes speech suggesting, ordering, and instructing. 9.86\% commissive speech includes threatening and promising speeches. Second, violations of the principle of Grice's cooperation are also found in the speech of Balinese subject teachers when managing classes. Violation of the quantity maxim is $42.86 \%$, violation of the quality maxim is $28.58 \%$, violation of the maxim of relevance is $14.28 \%$, and the violation of the maxim of the implementation is $14.28 \%$. Third, the Balinese speaking of Balinese language teachers has a very important role in supporting classroom management activities.
\end{abstract}

Published by IJRP.ORG. Selection and/or peer-review under responsibility of International Journal of Research Publications (IJRP.ORG)

Keywords: speech, Grice cooperation principle, class management

\section{Introduction}

Language has certain functions that are used based on one's needs, namely as a tool to express themselves, as a tool to communicate, as a tool for carrying out social integration and adaptation in certain environments or situations, and as a tool for exercising social control (Keraf, 1997: 2). According to Kridalaksana (1993: 12) language is an arbitrary sound symbol system, used by members of a community to work together, interact and identify themselves in everyday life, because humans use language to interact with one another.

The presence of language based on its function as a communication tool is very important in society. Communication skills that are emphasized in language teaching include four aspects, namely listening skills, 
speaking skills, reading skills, and writing skills (Tarigan, 1985: 2). The fourth sequence of skills is based on the level of ability obtained by a student preceded by listening, then try to express or say it, then understand the language in written form by learning to read, then reading ability is expressed in written form (Djamarah, 2005: 23).

An effective and interactive communication process basically involves two parties, namely the speaker and the interlocutor, while the interlocutor receives the information. If the information in the speaker's mind is conveyed, the communication can be said to be successful. The process of changing the conversation happened so quickly, it felt like a normal and natural event so that the communication went smoothly. A speaker needs to understand appropriate language to use in communicating well. In addition, to avoid misunderstandings that can make the other person offended or give a bad assessment of the speaker's personality. Speakers need to have the skills to choose and process words. One indicator of the success of language learning in schools is that teaching staff and students can use language well in communicating and interacting (Chaer, 2010: 32).

Good communication between teachers and students is needed in the learning process so that the learning atmosphere becomes conducive. Based on this, in order to communicate and exchange information properly, proper speech is needed. Sometimes the information has another meaning behind the utterances delivered. Teachers at SMAN 2 Kuta use language to interact emotions in communicating in class. This becomes a challenge for teaching staff to think of ways in guiding students to complete assignments properly, efficiently, and effectively. A teacher in teaching and learning activities in class should be able to create a comfortable learning atmosphere so that students have high enthusiasm in learning.

Based on preliminary observations, things were found that indicate that teaching and learning activities have not been carried out optimally in class management at SMAN 2 Kuta. Evidenced by the lack of enthusiasm of students in the teaching and learning process because the learning atmosphere is less conducive and communicative. This happens because a teacher should be able to manage the class well so that the teaching and learning process becomes more enjoyable and teaching and learning activities become more interesting. Good classroom management will facilitate a teaching staff in the process of delivering subject matter, as well as students more easily accept and understand the material delivered by the teaching staff. Thus, teaching and learning activities will run well.

One of the subjects that students are not interested in and that causes students to be less enthusiastic in taking lessons is the Balinese subject. Learning Balinese lessons is a challenge, maybe even a burden for those who learn it. Balinese language lessons are generally less desirable by students because Balinese is not too demanding in their daily lives. So, even though the subject is not in great demand, the subject of Balinese is one of the mandatory subjects that must be attended by all students at SMAN 2 Kuta.

Students certainly don't want to lose rankings because of the value of the renounced Balinese language lessons bye. In other words, they want to succeed in learning Balinese. Likewise, Balinese teachers do not want their students to be less successful in mastering their subject areas. For this reason, a strategy is needed to increase the success of students in learning Balinese. In addition, the quality and quality of the Balinese language teaching staff has a great influence on the success of learning Balinese. The success of educators in educating students not only depends on their attractive personality and impressive teaching, but also determined by the speech used in managing the class, the teaching staff will be better able to master the class so that it can improve the quality of teaching. If the class is orderly, teaching and learning activities will be more conducive.

A phenomenon that occurs when teaching staff who are giving or explaining Balinese subject matter that is less attractive to students, then these teachers often get scorn from students in carrying out their duties. It will complicate the implementation of the duties of an educator, even when students mock their teaching staff who are deemed to be inadequate in class, slow, excessive, inattentive, wordy, and other negative attitudes. In other words, the teaching staff lacks the ability to manage classes and teach well. As a result, students will complain to parents or other instructors that they do not like to be taught by these teachers. So, students look down on a teaching staff. 
Based on this phenomenon, it can be seen that the cause is the need for proper speech in managing the class. Therefore, the authors feel moved to conduct research related to speech, especially the subject of Balinese in classroom management. The researcher raised the title by focusing on the object of study of Balinese speech in managing classes and research subjects, namely the teachers of Balinese in SMAN 2 Kuta.

\section{Theoretical Framework}

\section{A. Speech Act Theory}

Speech act theory is a theory that examines the meaning of language based on the relationship of speech with the action taken by the speaker to the speech partner in communication. That is, speech is only meaningful if it is realized in an act of real communication. With regard to speech, Austin (1962: 37) classifies speech acts on three classifications, namely locus speech acts, illocutionary speech acts, and perlocutionary speech acts.

1) Locus Speech Acts

Locus speech acts are proposition actions that fall into the act of saying something category. Therefore, the priority in the act of locution is the content of the utterances expressed by the speaker. The act of locution is speeches containing statements or about something. Leech (1983: 54) states that the action of this language can more or less be equated with a sentence that contains meaning and reference.

2) Illocutionary Speech Acts

Illocutionary speech acts are speech acts that contain the power to perform certain actions in relation to saying something (an act of doing somethings in saying somethings). Such actions as promises, offers or questions revealed in the utterance. Austin (1962: 32) states that illocutionary acts are actual or actual speech acts that are formalized by speech, such as promises, remarks, and warnings. Identifying illocutionary acts is more difficult when compared to locutionary acts, because identifying illocutionary acts must consider the speaker and the speech partner, when and where the speech occurs.

3) Perlocutionary Speech Acts

Perlokusi speech acts are the effects or impacts caused by the speech against the speech partner, so that the speech partner acts based on the contents of the speech. Leech (1983: 61) states that the act of perlokusi is more concerned with results, because this action is said to be successful if the speech partner does something that is desired by the speaker.

\section{B. Classification of Speech Actions Based on the Speech Function}

Classification of speech acts based on the function of speech, Yule (2006: 92) states that the general classification system includes five types of public functions that are indicated by speech, namely declarative, representative, expressive, directive and commissive. The five classification systems can be explained as follows.

1) Declarative Speech

Declarative speech, namely illocution which is used to ensure compatibility between the contents of the proposition with reality, for example, validating or deciding, canceling, prohibiting, granting, punishing, forgiving and forgiving.

2) Representative Speech

Representative speech, namely illocution in which the speaker is bound to the truth of the preposition expressed, for example stating a fact, affirming, expressing opinions, reporting, conclusions and descriptions.

3) Expressive Speech

Expressive speech, which is an illocution that serves to express the psychological attitude of the speaker towards the situation implicit in the illocution, such as saying thank you, congratulating, apologizing, criticizing, and giving condolences.

4) Speech Directive 
Speech directive, which is an illocution which aims to produce an effect in the form of actions taken by the speech partner, such as ordering, commanding, asking, recommending, and advising.

5) Commissive Speeches

Commisitive speech, namely illocution where the speaker is bound to an action in the future, for example promising, offering, or vowing.

\section{Principle of Grice's Cooperation}

Grice (1975) identified that good communication must pay attention to the principle of cooperation. When communicating a speaker must pay attention to several things as follows.

1) Maximum Quantity (The Maxim of Quantity)

A speaker is expected to provide sufficient, relatively adequate, and as informative information as possible. Such information must not exceed the information actually needed by the speech partner. Speeches that contain information that is really needed by the speech partner, can be said to violate the quantity maxim in the Grice Cooperation Principle. And vice versa, if the speech contains excessive information it can be said to violate the quantity maxim.

2) The Maxim of Quality

A speech participant is expected to be able to convey something real and in accordance with the actual facts in speaking. That fact must be supported and based on clear evidence.

3) The Maxim of Relevance

The relevance maxim, it is stated that in order to establish good cooperation between the speaker and the speech partner, each should be able to make relevant contributions about something being spoken of. Speaking by not making such contributions is considered not to comply with and violate the principle of cooperation.

4) Implementation Maxim (The Maxim of Manner)

This implementation maxim requires that participants speak directly, clear and not blurred. People who speak without considering these things can be said to violate the Grice Cooperation Principle because they do not adhere to the implementation maxims.

\section{Principles of Class Management}

The principles of classroom management referred to by the principles of classroom management here are things that can be used as guidelines or guidelines for teachers in managing, so that they become directed and efficient. According to Djamarah, et al. (2005: 180) in order to minimize the problem of disruption in classroom management, the principles of classroom management can be used, namely:

1) Warm and enthusiastic. Warm and enthusiastic are needed in the teaching and learning process. Teachers who are warm and familiar with students always show enthusiasm in their assignments or in their activities will succeed in implementing classroom management.

2) Challenges The use of action words, ways of working or challenging materials will increase students' enthusiasm for learning thereby reducing the possibility of the appearance of deviant behavior. Additionally will be able to attract the attention of students and can control their learning passion.

3) Varying the use of tools or media, or aids, the teacher's teaching style, patterns of interaction between the teacher and students will reduce the appearance of disturbances, increase the attention of students. Especially if its use varies according to needs. Varying in the use of what is mentioned above is the key to achieving effective classroom management and avoiding saturation.

4) The flexibility of the teacher's behavior to change his teaching strategy can prevent the possibility of the emergence of student disruption, and create an effective teaching and learning climate. The flexibility of teaching can prevent the emergence of disturbances such as student commotion, no attention, not doing assignments and so on.

5) Emphasis on positive things. Basically in teaching and educating, teachers must emphasize the positive things and avoid focusing students' attention on negative things. Emphasis on positive things is 
the emphasis done by teachers on positive student behavior rather than nagging negative behavior. This emphasis can be done by providing positive reinforcement, and teacher awareness to avoid mistakes that can interfere with the learning process.

6) Cultivating self-discipline the ultimate goal of classroom management is students can develop self-discipline. Therefore, teachers should always encourage students to carry out self-discipline and the teacher himself should be an example of self-control and the implementation of responsibilities. So the teacher must be disciplined in everything if he wants his students to be disciplined in everything.

In line with the above disciplinary description, an orderly and orderly atmosphere full of dynamics in carrying out the planting of discipline in oneself will be realized if each person knows his position and function in class in order to carry out various activities.

\section{Methods}

This research uses the refer method. Listen method is a method used to obtain data by listening to the use of language. Named the method refer to because the method used to obtain data is by listening to the use of language (Mahsun, 2007: 29). The method of listening according to Sudaryanto (1993: 133) is divided into two techniques namely basic techniques and advanced techniques. The basic technique in this research is tapping technique. Researchers tapped someone or several people to get language data. Researchers tapped into the speech of Balinese language teachers at SMAN 2 Kuta. The advanced techniques are described into several techniques, namely: (1) a competent, free listening technique (SBLC), which is tapping, the researcher is not involved in teacher conversations in teaching and learning activities in class, (2) recording technique, this recording technique is carried out in line with SBLC technique, tapping is done by recording devices, (3) note taking technique, which is recording data on a data card. The use of this recording technique is also carried out to prevent the writer's negligence in using the notes technique of the conversation that occurred. In addition, the record technique also helps when data analysis is performed. The instrument used to document the utterances that take place is camcorders, camcorders, or cameras that can be used to record sounds and images. The recording process does not interfere with learning or does not engineer learning conditions so that the writer gets the desired data. Data collected from this recording technique is data of conversations that occur during learning. This conversation data is the main data source analyzed by the author to find the speech that occurs in the teacher's utterance. Furthermore, the data that has been collected is processed by the method of data analysis that has been prepared by the author so that the answers that appear can be as expected.

All data that has been collected through the listening method is then identified in accordance with the facts that occur in the field. Once identified, the data is then classified systematically based on sub-problems using analytic descriptive analysis methods and techniques. Descriptive analytic analysis is a study that seeks to describe a symptom of events and events that occur at the present time, researchers trying to photograph events and events that are the center of attention and then described as they are (Sudjana, 1989: 64). The steps in data analysis are as follows. Make transcription of recorded teaching and learning processes into a discourse. Making a corpus of data about teacher interactions in classroom management activities obtained through learning records. Classification of Balinese speech data according to its speech function. Classification of data according to the principle of Grice cooperation. Analyzing data to find out the role of Balinese speech in classroom management. Formulation of conclusions regarding the function of speech, violation of the principle of Grice's cooperation, and the role of speech in supporting classroom management activities.

The method for discussing the results of this study is an informal method. The informal method is used in the form of describing ordinary words so that the explanation seems detailed and decomposed (Sudaryanto, 1993: 145). Based on this explanation, this writing uses the informal method because in presenting the results of research it only uses a series of words and regular sentences. The informal method used to discuss the results of this study will be assisted with a mindset based on deductive and inductive techniques. Deductive mindset is making a specific interpretation based on a general problem, while what is meant by the inductive 
mindset is a mindset that is real and is used to interpret general problems (Sutrisnohadi, 1977: 46-49).

The methods and techniques for presenting the results of this data analysis are used to describe teachers' speeches based on their functions, describe violations of the principle of Grice's cooperation, and explain the role of speech in supporting classroom management activities.

\section{Results and Discussions}

\section{A. Percentage of Occurrence of Speech Functions}

Based on the analysis of the findings in this study found 41 speech events consisting of 5 declarative speeches representing 22 as many as 3, expressive 3 as many as 7 directives, and commisive as many as 4 . Based on these data, then the appearance of speech functions can be presented as follows.

1) Declarative Speech

$(5: 41) \times 100=12.20 \%$

2) Representative Speech

(22: 41$) \times 100=53.65 \%$

3) Expressive Speech

(3: 41$) \times 100=7.32 \%$

4) Speech Directive

$(7: 41) \times 100=17.07 \%$

5) Commissive Speeches

$(4: 41) \times 100=9.76 \%$

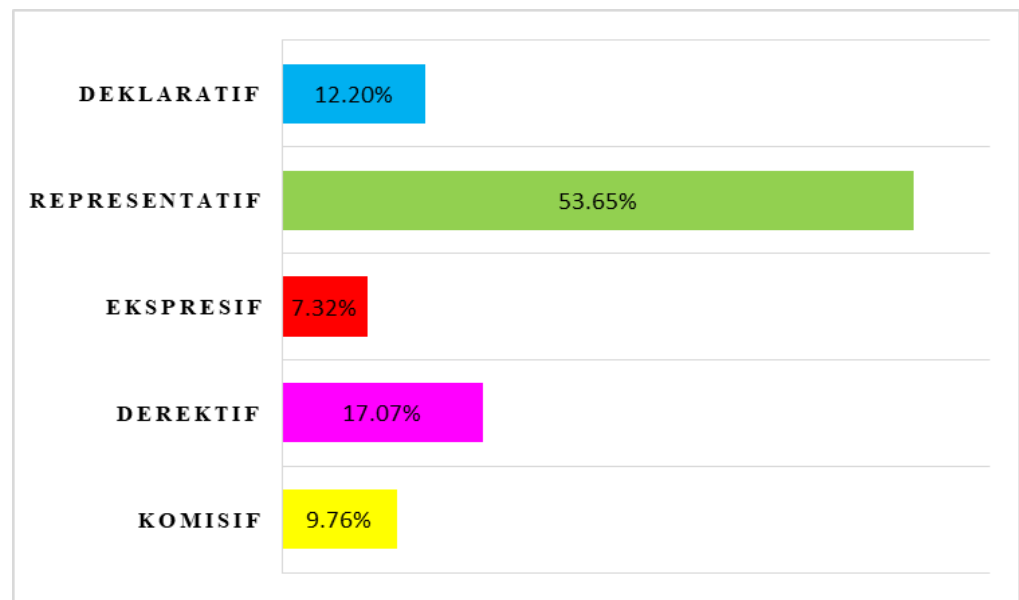

Diagram Percentage of Appearance of Balinese Speech Functions of

Balinese Subject Teachers in Classroom Management at SMAN 2 Kuta.

Based on the number of utterances obtained from the findings of this study in the event of speech during class management activities, the total number of teacher utterances if sorted out includes the most representative functions of speech as much as $53.65 \%$, directive function of speech as much as $17.07 \%$, declarative speech function of $12.20 \%$, the commissive speech function of $9.76 \%$, and the expressive speech function of $7.32 \%$. 


\section{B. Percentage of Occurrence Violations of Grice's Cooperation Principle in Class Management} Activities

Violations of the principle of Grice's cooperation are often done by teachers with the aim to facilitate the teacher in managing the class. Based on the findings in the study, the violation of the principle of Grice cooperation can be summarized as follows.

1) Maximum Quantity Violation

$(3: 7) \times 100=42.86 \%$

2) Quality Maximum Violations

$(2: 7) \times 100=28.58 \%$

3) Violation of Maximum Relevance

$(1: 7) \times 100=14.28 \%$

4) Violation of Maximum Implementation

(1: 7$)$ x $100=14.28 \%$

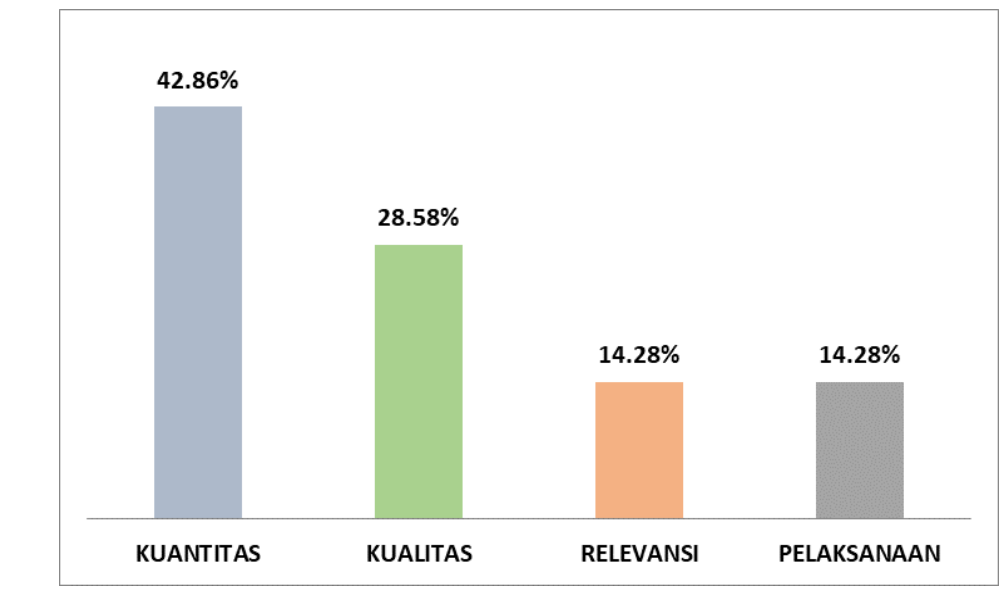

Diagram Percentage of Violations in Appearance of Grice's Collaboration

in Class Management at SMAN 2 Kuta

Based on the number of violations of the Grice cooperation principle obtained from the findings of this study, it can be explained by the percentage of violations of quantity maxim maxim of $42.86 \%$, violations of quality maxim of $28.58 \%$, violations of relevance maxim of $14.28 \%$, and violations of implementation maxim of as much as $14.28 \%$. Based on these data, the most dominant violation of the Grice cooperation principle committed by the teacher is the quantity maxim.

\section{The Role of Balinese Language Speech Balinese Subject Teachers in Supporting Classroom} Management Activities

This problem is analyzed through the speech function found in the speech events between the teacher and students during class management activities. Speech has a very important role in supporting classroom management activities. Based on the analysis of speech events in classroom management, these roles can be specified as follows.

1) The declarative 'classifying' role is to provide a deterrent effect for students not to repeat the mistakes made. In addition, it can also make other students not dare to cause trouble or commotion in the 
classroom.

2) Declarative speech 'forbid' aims to remind students This function is to instill discipline and ethics in using language. Teachers need speech like this in order to motivate students to carry out self-discipline, then the teacher must also be an example for students because the teacher is a model that is imitated and innocent.

3) Declarative speech 'forgive' role to reprimand students who do not follow the rules that have been made by the teacher. Students who do not obey the teacher are very disturbing teaching and learning process that takes place, so it needs to be given a reprimand, if necessary sanctions in accordance with student mistakes. Every student who is reprimanded will feel ashamed and immediately apologize for his mistakes. The teacher will indirectly forgive the student with some advice and suggestions that can make the student better.

4) Representative speech 'shows' role to provide information that can enhance student learning and development. Aside from being a facilitator, the teacher also has a duty to educate, teach and guide students to be better intellectually and emotionally.

5) Representative speech 'speculation' has a role to arouse students' memory about the material that has been learned and motivates students to be enthusiastic and active in receiving lessons and discussions.

6) Representative speech 'states' play a role in increasing students 'responses to the stimulus provided by the teacher and can increase students' interest or concentration in attending the lesson. The attractiveness, motivation, and enthusiasm of students in following ongoing lessons.

7) Representative speech 'recognizes' intends to equalize degrees between teacher and student while showing students that not only students learn, but teachers also always learn.

8) Expressive speech 'praising' aims to make students more active in the learning process and make it easier for teachers to manage the class. Giving a little praise to students, at least can increase student enthusiasm in learning, so students will concentrate more on receiving subject matter.

9) Expressive utterance 'satire' means that students take an active role and ask questions about things that are not understood by students, not just listening to the teacher's explanation.

10) The directive utterance 'suggests' aims to provide positive suggestions for students to become students who are disciplined, diligent, smart, polite, and ethical.

11) Speech directive 'commanding' aims to force students to play an active role in the teaching and learning process, so that they can red the maximum value according to their abilities.

12) The 'direct' speech directive is the same as the 'directive' directive speech, it's just that the way to pronounce it is more subtle and polite. This speech aims to determine the ability of students, how well they understand in receiving lessons, and indirectly force students to think, imagine, and be active in the teaching and learning process.

13) Commissive speech 'threatening' is useful to create a deterrent effect for students who do not pay attention to the teacher's explanation with the aim that students can concentrate more on following the teaching and learning process.

14) Commissive speech 'promises' aims to remind students to relearn what has been learned at school and remind students to study subject material for the next meeting.

All of these speech functions are very instrumental in supporting classroom management activities. The teacher is easier to create an optimal learning atmosphere and restore a learning atmosphere that is already noisy, uncomfortable, and uneasy to be conducive. A conducive learning atmosphere will make students comfortable accepting lessons and the teacher also has an easier time managing class.

\section{Conclusions}

Based on the results and discussions, it can be concluded that:

1) The answer to the first problem regarding teacher speech in classroom management activities. Each teacher has different characteristics in teaching in the classroom by using various speech functions in classroom management. Declarative speech that is used in class management activities is spoken by the 
teacher as much as $12.20 \%$, namely speech classifying, prohibiting, and forgiving. Representative speech spoken by the teacher as much as $53.65 \%$, including speech shows, speculation, states, and acknowledges. Expressive speech spoken by the teacher as much as $7.32 \%$, including praise and insinuation. The directive utterances spoken by the teacher were $17.07 \%$, namely the suggestions, orders and orders. Finally, the commissive speech spoken by the teacher was $9.76 \%$. Based on this, the most dominant speech function is representative speech. Through this speech the teacher can provide corrections to mistakes made by students, point out things that must be considered, and things that should be avoided in the teaching and learning process. Representative utterances found in this study include showing, speculating, stating, and acknowledging. Based on the representative speech function, the 'stated' speech function is used more often by the teacher.

2) Violations of the principle of Grice cooperation also occur in Balinese language speech of Balinese subject teachers during class management. In terms of pragmatics, teacher's speech does violate the principle of Grice's cooperation, but in the world of education these violations are indispensable with specific aims and objectives. These violations include maxim of quantity, maxim of quality, maxim of relevance, and maxim of implementation. Violation of the quantity maxim is $42.86 \%$, violation of the quality maxim is $28.58 \%$, violation of the maxim of relevance is $14.28 \%$, and the violation of the maxim of the implementation is $14.28 \%$. The most dominant maxim that is violated is the maxim of quantity because the teacher conveys information at length and is excessive. This is because the teacher wants to emphasize the subject matter to students so that it is easier to understand. Breaches of quality maxims occur because of a lack of response, enthusiasm and interest in student learning. Maximization relevance is violated with the aim of creating a conducive learning atmosphere. The implementation maxims are violated aiming to restore the passion of students in the teaching and learning process. All violations of the principle of Grice's cooperation are carried out with the aim of creating optimal learning conditions, so that classroom management activities can proceed well.

3) Based on the analysis of the utterances along with the function of the utterances it was found several roles of each of the speech functions. Declarative speech acts to provide a deterrent effect for students not to repeat mistakes made and to give shame to students who make a fuss in class so that the atmosphere of learning is conducive again. Representative speech acts to tell students that negative attitudes are not worth imitating. Representative speech aims to motivate students to be enthusiastic in accepting lessons and be active in discussions, and increase students' responses to stimuli provided by the teacher and can increase student interest and concentration. Expressive speech acts to respect students because by respecting students the teacher will also be appreciated so that a good relationship exists between the teacher and students. The existence of a good relationship between students and teachers will facilitate the teacher in conducting classroom management. Speech directive aims to provide positive suggestions for students to become students who are disciplined, diligent, smart, polite, and ethical. Speech directive aims to force students to actively participate in the teaching and learning process in order to achieve maximum value in accordance with students' abilities. Commissive speech aims to create a deterrent effect for students who do not pay attention to the teacher's explanation with the aim that students can concentrate more on following the teaching and learning process. Commissive speech also aims to remind students to relearn what has been learned at school and remind students to learn subject material for the next meeting. In addition to analyzing through its speech function, the role of speech is also analyzed through a questionnaire distributed to teachers of Balinese in SMAN 2 Kuta. Based on this, it is known that speech plays a very important role in classroom management activities, and communication is needed to support the success of classroom management. Therefore, the speech can help students to improve student discipline in following the learning process.

\section{References}

Aridah. 2013. Politeness Phenomena as a Source of Pragmatic Failure in English as a Second Language. TEFLIN Journal, 24 (1). 
Arikunto, Suharsimi. 1988. Prosedur Penelitian Suatu Pendekatan Praktek. Jakarta: PT Rineka Cipta.

Austin, J. L. 1962. How do to Things with Words. Oxford: The Clarendon Press.

Brown, P. \& Levinson, S. 1987. Politeness: Some Universals in Language Usage. Cambridge: Cambridge University Press.

Chaer, Abdul. 2004. Tata Bahasa Praktis Bahasa Indonesia. Jakarta: Rineka Cipta.

Djamarah, S. B. 2005. Strategi Belajar Mengajar. Bandung: CV. Sinar Baru.

Fraser, Bruce. 1978. Acguiring Social Competence In a Second Language. RELC Jurnal 9:1-21.

Grice, Herbert Paul. 1975. Logic and Conversation. New York: Academic Press.

Keraf, Gorys. 1997. Komposisi. Jakarta: Ikrar Mandiri Abadi.

Kridalaksana, H. 1993. Kamus Linguistik (3rd ed.). Jakarta: Gramedia.

Lakoff, R. 1973. The Logic of Politeness: or, Minding your pees and qees. In C. Corum, T. C. Smith-Stark \& A. Weiser (Eds.), Papers from the Ninth Regional Meeting of the Chicago Linguistic Society (pp. 345-356). Chicago: Chicago Linguistic Society.

Leech, G. 1983. Principles of Pragmatics. New York: Longman Inc.

Mahsun. 2007. Metodologi Penelitian Bahasa: Tahap Stategi, Metode dan Tekniknya. Jakarta: PT. Raja Grafindo Persada.

Noddings, N. 1995. Philosophy of Education. Colorado: Westview Press, Inc.

Sudaryanto. 1993. Metode dan Aneka Teknik Analisis Bahasa (Pengantar Penelitian Wahana Kebudayaan Secara Linguistik). Yogyakarta: Duta Wacana University Press.

Sudjana, N. 1989. Dasar - Dasar Proses Belajar Mengajar. Bandung: Sinarbaru.

Sutrisnohadi. 1977. Metodologi Research. Yogyakarta: Yayasan Penerbit Fakultas Psikologi Universitas Gajah Mada.

Suwarna. 2005. Pengajaran Mikro.Yogyakarta: Tiara Wacana.

Tarigan, Henry Guntur. 1985. Prinsip-prinsip Dasar Sastra. Bandung: Angkasa.

Tarigan, Henry Guntur. 1990. Pengajaran Pragmatik. Bandung: Angkasa Bandung.

Unal, Z. \& Unal, A. 2012. The Impact of Years of Teaching Experience on the Classroom Management Approaches of Elementary School Teacher. International Journal of Instruction, 5(2), 41-60.

Wardani, I.G.A.K. (2005). Pemantapan Kemampuan Mengajar (PKM). Jakarta: Universitas Terbuka.

Yule, George. 2006. Pragmatik. Yogyakarta: Pustaka Pelajar. 